\title{
The Origins of the Right to Science
}

\section{The American Declaration on the Rights and Duties of Man}

\author{
Cesare P. R. Romano
}

\subsection{INTRODUCTION}

If one were to pinpoint a day and place where the "right to science" was born, it would be December 31, 1945, in Rio de Janeiro, Brazil. On the last day of the year that saw the end of World War II, four members of the Inter-American Juridical Committee gathered to adopt the first draft of the future American Declaration on the Rights and Duties of Man (American Declaration). ${ }^{1}$ In it, they described a new human right, never articulated before: the right to benefit from progress in science and technology, also known more succinctly as "the right to science". Although reworded and re-elaborated, the right survived two drafts and the negotiating process to end up in Article XIII of the American Declaration. In turn, that provided the essential wording for Article 27.1 of the Universal Declaration of Human Rights (Universal Declaration), ${ }^{2}$ which then led to Article 15 of the International Covenant on Economic, Social and Cultural Rights (ICESCR), ${ }^{3}$ and several other human rights treaties and declarations. ${ }^{4}$

This chapter tells the story of the drafting and adoption of the American Declaration, and in particular of its provisions on the right to science and the "rights of science (i.e. the human rights that are most crucial for the work of scientists and inventors, such as freedom of thought, academic freedom, intellectual property, and others).

1 American Declaration of the Rights and Duties of Man, adopted on May 2, 1948 by the Ninth International Conference of American States, OAS Res XXX, reprinted in Basic Documents Pertaining to Human Rights in the Inter-American System, OEA/Ser L V/II.82 Doc 6 Rev 1, at 17 (1992).

2 Universal Declaration of Human Rights, adopted December 10, 1948, UNGA Res 217A (III) (UDHR).

3 International Covenant on Economic, Social and Cultural Rights, adopted December 16, 1966, entered into force January 3,1976, 993 UNTS 3.

4 Additional Protocol to the American Convention on Human Rights in the Area of Economic, Social, and Cultural Rights (Protocol of San Salvador), November 17, 1988, OASTS No. 69, Art. 14.1.b; (Revised) Arab Charter on Human Rights, May 22, 2004, reprinted in 12 Int'l Hum. Rts. Rep. 893 (2005), Art. 42.1; Association of Southeast Asian Nations (ASEAN) Human Rights Declaration, November 18, 2012, Art. 32 . 
The American Declaration is the first broad and detailed enumeration of human rights to be adopted by an intergovernmental organization. Although the Universal Declaration is hailed as the founding document of international human rights, it is often forgotten that it was preceded and inspired by the American Declaration. ${ }^{5}$ While the Universal and the American declarations were largely drafted in parallel, the drafting of the American Declaration was always a couple of steps ahead. Indeed, the Inter-American Judicial Committee adopted the first draft of the American Declaration at the end of December 1945, only six months after the San Francisco conference, which established the United Nations, had concluded (June 1945). The first draft was published in March 1946, before the UN Preparatory Committee tasked with drafting the Universal Declaration had even held its first meeting. The American Declaration was completed before the second round of drafting of the Universal Declaration, and was adopted on May 2, 1948, almost eight months before the Universal Declaration (December 10, 1948). There is no doubt that the American Declaration heavily influenced the drafting process and final wording of the universal one. ${ }^{6}$

The fact that the American Declaration is the source of the language used in the corresponding provisions of the Universal Declaration, and, partly, of the ICESCR, is already sufficient to warrant a chapter in this book. However, there is also an operative and autonomous justification for this exposé. Indeed, in the Western hemisphere there are some major states, such as the United States and Cuba, which have not ratified the American Convention or the ICESCR. Because of that, the Universal Declaration and the American Declaration are the only codified international human rights standards applicable to them. While the Universal Declaration does not have a specific mechanism to ensure compliance other than the generic Universal Periodic Review, ${ }^{7}$ the American Declaration can be invoked before a specific quasi-judicial body, the Inter-American Commission on Human Rights. ${ }^{8}$ Although, to the best of my

5 On the contribution of the American Declaration to the construction of the international system of protection of human rights, see, in general: Kathryn Sikkink, "Latin American Countries as Norm Protagonists of the Idea of International Human Rights", Global Governance, Vol. 20 (2014), p. 396; Tom Farer, "The Rise of the Inter-American Human Rights Regime: No Longer a Unicorn, Not Yet an Ox," in David Harris and Stephen Livingstone, eds., The Inter-American System of Human Rights, Oxford University Press, 1998, p. 35; Ana Elizabeth Villalta Vizcarra, "La Contribución de América al Derecho Internacional," in Organización de los Estados Americanos, XXXIII Curso de Derecho Internacional (2006): El Derecho Internacional en las Américas: 100 años del Comité Jurídico Interamericano, 2006, pp. 167-187; Claudio Grossman, "American Declaration of the Rights and Duties of Man (1948)," in Max Planck Encyclopedia of Public International Law (hereafter MPEPIL); Johannes Morsink, The Universal Declaration of Human Rights: Origins, Drafting, and Intent, University of Pennsylvania Press, 1999, pp. 130-134; Paolo Carozza, "From Conquest to Constitutions: Retrieving a Latin American Tradition of the Idea of Human Rights," Human Rights Quarterly, Vol. 25, 2003, p. 281; Mary Ann Glendon, "The Forgotten Crucible: The Latin American Influence on the Universal Human Rights Idea," Harvard Human Rights Journal, Vol. 16, 2003, p. 27.

Morsink, supra note 5, p. 130.

7 Christian Tomuschat, "Universal Periodic Review Procedure: Human Rights Council," MPEPIL.

8 The Inter-American Commission on Human Rights and the Inter-American Court of Human Rights have maintained that the American Declaration has acquired legally binding force. When the OAS 
knowledge, to date there has been no petition brought before the Inter-American Commission claiming a violation of the right to science or the rights of science the possibility exists.

\subsection{THE DRAFTING HISTORY OF THE AMERICAN DECLARATION}

From August 21, 1944 to October 7, 1944, as the Allied forces were inching closer to Berlin and Tokyo, the "Four Policemen" (the U.S., UK, USSR and China) met at the Dumbarton Oaks estate, in Washington D.C., to discuss the creation of future international organizations to ensure international peace and security, leading eventually to the creation of the United Nations. Despite being members of the Allied coalition, Latin American countries were not invited. That snub, and also because discussions at Dumbarton Oaks did not include various issues of their concern, including human rights, ${ }^{9}$ caused Latin American countries to move ahead on a parallel track to discuss the creation of similar institutions for the Western hemisphere, eventually leading to the creation of the Organization of American States (OAS).

Thus, from February 21 to March 8, 1945, twenty members of the Pan-American Union gathered near the park of Chapultepec, in Mexico City, to discuss the "Project of Organic Pact of the Inter-American System," with the goal to reorganize

Charter was amended in 1967 , several references to human rights were included. Yet, at that time, the only exhaustive list of human rights in the OAS system was the American Declaration. Because of that, the Commission and the Court have concluded that the OAS members must have had the intention to incorporate it into the OAS Charter. Moreover, the OAS members accepted the ${ }_{1967}$ OAS Charter amendments, and the General Assembly of the OAS has repeatedly declared that the American Declaration is a source of international obligations for its members. Interpretation of the American Declaration of the Rights and Duties of Man Within the Framework of Article 64 of the American Convention on Human Rights, Advisory Opinion, OC-1o/89, Inter-Am. Ct. H.R., (Ser. A) No. 10 (July 14, 1989), paras. 39-43; Christina Cerna, "Reflections on the Normative Status of the American Declaration of the Rights and Duties of Man," University of Pennsylvania Journal of International Law, Vol. 30, 2009, p. 1212.

Although the U.S. government insists the American Declaration does not bind it legally, it has participated in proceedings before the Commission when individuals have brought petition accusing it of having violated the Declaration, and, in several cases, it has taken steps to get back into compliance when the Commission found it in violation of the Declaration. Elizabeth Abi-Mershed, "The United States and the Inter-American Court of Human Rights," in Cesare Romano (ed.), The Sword and the Scales: The United States and International Courts and Tribunals, Cambridge University Press, 2009, pp. 185-209. Although U.S. courts hold that they are not bound to give effect to the reports on petitions of the Inter-American Commission, they stop short of saying they are not binding at all. They rather say that they are aimed at the executive and legislature, and not the judiciary. For one example of this consistent approach, see Thompson v. State of Tennessee, 134 S.W. 3d 168.

9 "Latin American countries felt betrayed because they had not been involved in the Dumbarton Oaks discussion about a postwar organization, and also because the Dumbarton Oaks draft did not incorporate various ideals they supported, including human rights." Sikkink, supra note 5, p. 393, citing Paul Gordon Lauren, The Evolution of International Human Rights: Visions Seen, University of Pennsylvania Press, 1998, pp. 174-179. 
inter-American cooperation and to coordinate with the soon-to-be United Nations. ${ }^{10}$ At the Chapultepec conference, the participating states decided that the Organic Pact would be accompanied by two declarations: one on the "rights and duties of states" and a second on the "rights and duties of man". "The first was to be a declaration of rights and duties of states vis-à-vis each other, codifying principles of nonintervention, prohibition of aggression, peaceful settlement of disputes, and the like. The second, however, was to lay down duties states had vis-à-vis their citizens and other persons within their jurisdiction, that is to say human rights, as well as duties that those individuals owed to the states. ${ }^{12}$ The drafting of the former was entrusted to the Governing Board of the Pan American Union (a body made of representatives of member states), while the Inter-American Juridical Committee (Comité Jurídico Interamericano - Comissão Jurídica Interamericana) was given the task to draft the latter. ${ }^{13}$

\subsubsection{The Work of the Inter-American Juridical Committee}

The Inter-American Juridical Committee was - and still is - a group of independent jurists, headquartered in Rio de Janeiro, Brazil. ${ }^{14}$ Its function is to develop and coordinate the work of the codification of international law, and in particular "American international law," meaning the rules of international law specific to

10 They were Bolivia, Brazil, Chile, Colombia, Costa Rica, Cuba, Dominican Republic, Ecuador, El Salvador, Guatemala, Haiti, Honduras, Mexico, Nicaragua, Panama, Paraguay, Peru, Uruguay, USA, and Venezuela. Argentina, despite being a member of the Union, was not invited because it had not joined the Allied side until late during the war. However, it signed the final resolution of the Chapultepec Conference. Canada and the various European territories and colonies in the Caribbean were not part of the inter-American system and did not participate to the Chapultepec conference, nor the Bogotá conference, which created the OAS and adopted the American Declaration of the Rights and Duties of Man. Josef Kunz, "The Inter-American Conference on the Problems of War and Peace at Mexico City and the Problem of the Reorganization of the Inter-American System," American Journal of International Law, Vol. 39, No. 3 (1945), pp. 527-533.

1 U.S. Department of State, Ninth International Conference of American States, Bogotá, Colombia, March 30-May 2, Report of the Delegation of the United States of America with Related Documents, Department of State Publication 3263, Division of Publications, Office of Public Affairs, Washington D.C., November 1948 [hereinafter Ninth International Conference], p. 3. At an earlier meeting of the Inter-American Bar Association in Mexico City in 1944, resolutions had also emphasized the "necessity" of a declaration of rights of man, and the importance of international machinery and procedures to put the principles in the declaration into action. Sikkink, supra note 5, pp. 393-394.

12 In particular, Resolution XL of March 7, 1945 on the International Protection of the Essential Rights of Man proclaimed that "the American Republics" would adhere to "the principles established by international law for safeguarding essential rights of man," and declared, in its preamble, the need to define such rights and duties, calling for the creation of a regional system for their protection. U.S. Department of State, Report of the Delegation of the United States of America to the Inter-American Conference on Problems of War and Peace, U.S. Government Printing Office, Washington 1946, pp. 108-109.

13 U.S. Report, Ninth International Conference, supra note 11, p. 3.

14 On the Inter-American Juridical Committee, see, in general, Fernanda Millicay, "Inter-American Juridical Committee," MPEPIL. 
the Americas. However, it is obvious that drafting a declaration on the rights and duties of man was an exercise that required going beyond mere codification of international law. It was squarely a matter of progressive development. Although during the interwar and war years, a number of projects of international declarations of human rights and freedoms had been prepared by various organization and societies, many of which were in Latin America, ${ }^{15}$ at that time state practice was, at best, vague and scant or, in the case of the right to science, completely nonexistent. ${ }^{16}$

The Committee started working in earnest right after the closing of the Chapultepec conference. Within nine months, they had produced a first draft titled "Anteproyecto de declaracion del los derechos y deberes internacionales del hombre" (Preliminary Draft of a Declaration on the Rights and Duties of Men). ${ }^{17}$ A second draft, titled "Proyecto Definitivo" (Final Draft) took two more years, since state members of the Inter-American system had been given the opportunity to comment. It was adopted on December $8,1947 \cdot{ }^{18}$

At the time the America Declaration was drafted, the Committee was composed of seven members (as opposed to eleven nowadays) nominated by the governments of Argentina, Brazil, Chile, Cuba, Mexico, the United States, and Venezuela. ${ }^{19}$ The Chapultepec Conference added two more members (Colombia and Peru). ${ }^{2 \circ}$ However, in total only six members signed the two drafts the Committee produced (and presumably participated in their preparation). ${ }^{21}$ Charles Fenwick (United

15 See Hector Gros Espiell, Derechos Humanos y Vida Internacional, Instituto de Investigaciones Jurídicas, Comisión Nacional de Derechos Humanos, México, 1995, p. 16, note 9.

16 Richard Pierre Claude, Science in the Service of Human Rights, University of Philadelphia Press, 2002, p. 35 .

17 Comité Jurídico Interamericano, "Anteproyecto de declaración de los derechos y deberes internacionales del hombre, Rio de Janeiro, 31 dicembre 1945," in Comité Jurídico Interamericano, Recomendaciones e informes, Documentos Oficiales (1945-1947), Departamento de Imprensa Nacional, Rio de Janeiro, 1950, pp. 49-59. For the commentary, see "Informe anexo al anteproyecto de declaración de los derechos y deberes internacionales del hombre", ibid., p. 61-115. The English version of the Draft Declaration, including a commentary, can be found in Pan American Union, Draft Declaration of the International Rights and Duties of Man and Accompanying Report, Formulated by the Inter-American Juridical Committee in accordance with Resolutions IX and XL of the Inter-American Conference on Problems of War and Peace held at Mexico City, February 21March 8, 1945, Pan American Union, Washington DC, March 1946 [hereinafter First Draft].

18 Comité Jurídico Interamericano, Declaración de los derechos y deberes internacionales del hombre, Rio de Janeiro, December 8, 1947, in Comité Jurídico Interamericano, Recomendaciones e informes, Documentos Oficiales (1945-1947), pp. 185-193. The English version of the second draft can be found in Ninth International Conference, supra note 11, pp. 115-120, or in Thomas Buergenthal and Robert E. Norris, eds. Human Rights: The Inter-American System, Oceana Publications (loose-leaf format), Part I, Chapter IV, p. 9 (Section C). The Commentary of the second draft can be found at p. $195 \mathrm{ff}$ and in Ministerio de Relaciones Exteriores de Colombia, IX Conferencia Internacional Americana, Bogotá, 1949, Actas y Documentos, Bogotá, 1953, Vol. V, pp. 454-458 [hereinafter IX Conferencia].

19 José Joaquín Caicedo Castilla, The Work of the Inter-American Juridical Committee, Pan American Union, OAS, 1964, p. 4.

20 Ibid.

${ }^{21}$ It is not clear why not all members of the Committee participated in the preparation of the drafts. José Joaquín Caicedo Castilla, who was member of the Inter-American Juridical Committee for thirty-three 
States) and Francisco Campos (Brazil) signed both drafts, while Felix Nieto del Río (Chile) and Antonio Gómez Robledo (Mexico) signed the first draft, and José Joaquín Caicedo Castilla (Colombia) and Eduardo Arroyo Lameda (Venezuela) the second. They were all scholars and diplomats, each bringing their own unique perspective to the task. ${ }^{22}$ Curiously, many of them were not formally trained in law or had never practiced law. ${ }^{23}$

A Brazilian, as a tribute to the country hosting it, traditionally chaired the Committee. ${ }^{24}$ At the time of the drafting of the Declaration, the Brazilian member was Francisco Luís da Silva Campos, a jurist, attorney, legal scholar, and politician. A scion of families that dominated the economic, political, and social life of Brazil of the late XIX century, Campos was the author of Brazil's Constitution of 1937, and of the criminal and criminal procedural codes of Brazil, which, in substance, are still in force in Brazil to this day. ${ }^{25}$ That, and the fact that history remembers him for his authoritarian and anti-liberal views of the state and democracy, made him an unlikely author of a declaration of human rights. ${ }^{26}$

Although he was a political scientist by training (Ph.D. in political science from Johns Hopkins University, in 1912) and never earned a law degree, Charles Ghequiere Fenwick was considered one of the distinguished international lawyers and scholars of his time. ${ }^{27}$ He was professor of political science at Bryn Mawr College from 1918 to 1947 and President of the American Society of International Law (1953-1954). ${ }^{28}$ After having worked on the draft of the American Declaration at the Inter-American Juridical Committee, he became director of the Department of

years, from July 3, 1946 to his death, on December 15, 1979, suggests it might be because not all members where in Rio at that time. "At first the Committee met all through the year and the members lived in Rio. However, although apparently paradoxical, experience showed that this was not the best system, because the necessary quorum for the adoption of a decision was often lacking." Ibid., p. 13.

22 As it has been noted, Latin American scholars and politicians are neither fully Western nor nonWestern. The West/non-West dichotomy in international relations scholarship hides unique Latin American contributions. Louise Fawcett, "Between West and Non-West: Latin American Contributions to International Thought," International History Review, Vol. 34, no. 4 (2012), pp. 679-704. Instead, Liliana Obregón Tarazona speaks of a "creole" legal consciousness that blends elements unique to the Latin American experience with international legal traditions of the time. Liliana Obregón, "Between Civilization and Barbarism: Creole Interventions in International Law," Third World Quarterly, Vol. 27, no. 5 (2006), pp. 815-832.

23 Yet, as Charles Fenwick noted while commenting the Committee's statute, "the members of the Committee should be jurists [and] should have "no other duties than those pertaining to the Committee." This provision was directed against the appointment by several Governments of their diplomatic representatives in Rio as members of the Committee". Charles G. Fenwick, "The InterAmerican Juridical Committee," American Journal of International Law, Vol. 37, no. 1 (1943), pp. $5-29$, at 7 and 8 .

24 Caicedo, supra note 19, p. 12.

25 https://cpdoc.fgv.br/producao/dossies/AEraVargasi/biografias/francisco_campos

26 Ibid.

27 www.nytimes.com/1973/04/26/archives/charles-g-fenwick-dies-at-92-was-international-law-expert.html.

28 Ibid. 
International Law of the Pan American Union, and later of the Organization of American States. ${ }^{29}$

Felix Nieto del Río studied law but never practiced or taught it. He had a career as a journalist and writer first, and then as a diplomat. ${ }^{30}$ He entered public service as employee of the National Library and later of the Ministry of Foreign Affairs. ${ }^{31} \mathrm{He}$ became a diplomat, representing Chile in several capitals in Europe and the Americas. He was Chile's ambassador to Brazil (1936-1939) and to the U.S. (1947-1952), ${ }^{32}$ and, crucially, he represented Chile at the first meeting of the UN Human Rights Commission, the body that drafted the Universal Declaration of Human Rights, ensuring continuity between the two.

Like Nieto del Río, Antonio Gómez Robledo was also a diplomat by trade. ${ }^{3}$ Yet, he was a philosopher and legal scholar of the first order, too. ${ }^{34}$ Born from a wealthy family in Guadalajara, Mexico, he read law at the University of Guadalajara. ${ }^{35}$ Before joining the Mexican diplomatic service, in 1936, he earned a doctorate in philosophy from the Universidad Nacional Autónoma de Mexico, and studied in Paris, The Hague, New York (Fordham University) and Rio. ${ }^{36}$ After retiring from the diplomatic service, he went back to academia and scholarly writing, publishing on Plato and Socrates, on the origins of international law and its early writers, and various works on catholic issues. ${ }^{37}$

In 1946, after the first draft had been adopted and before the second and final one was prepared, José Joaquín Caicedo Castilla and Eduardo Arroyo Lameda replaced Nieto del Río and Gómez Robledo in the Committee.

Arroyo Lameda was a poet and writer, with a respectable publishing and prizes record, member and director of the Venezuelan Academy of Language (Academia Venezoelana de la Lengua). ${ }^{8}$ He studied literature first, and then obtained a doctorate in Political Science from the Central University of Venezuela. ${ }^{39}$ The study of law, which he undertook subsequently, seemed to be an afterthought. Later he became professor of diplomatic history and international relations. ${ }^{40}$

29 Ibid.

30 Sergio Martínez Baeza, "En el cincuentenario de su muerte. Félix Nieto del Rio, 1888-1953," Boletín de la Academia Chilena de la Historia, no. 133, 2004; https://es.wikipedia.org/wiki/F\% $3 \%$ Aglix_Nieto_del_R\%C3\%ADo.

${ }^{31}$ Ibid.

32 Ibid.

33 Marta Morineau, Antonio Gómez Robledo, Vida y Obra, Anuario mexicano de historia del derecho, no. 17, 2005, pp. 219-239; https://es.wikipedia.org/wiki/Antonio_G\%C3\%B3mez_Robledo.

34 Ibid.

35 Ibid

${ }_{3} 6$ Ibid

37 Ibid.

$3^{8}$ Jose Román Duque Sanchez, "Homenaje al Dr. Eduardo Arroyo Lameda con motivo del centenario de su nacimiento," Boletín de la Academia de Ciencias Políticas y Sociales, Vol. 67, no. 123, 1991, pp. $241-246$.

39 Ibid.

$4^{\circ}$ Ibid. 
Of the six men who participated in the drafting of the American Declaration, José Joaquín Caicedo Castilla probably had the strongest international law credentials. ${ }^{41}$ He graduated in law and political science from the National University of Colombia. ${ }^{42}$ He was Judge ad hoc of the International Court of Justice in the Haya de la Torre case ${ }^{43}$ and served both as elected member of both the parliament and the Senate of Colombia, as minister of the government (Work and Social Affairs first, and then Foreign Affairs), as Ambassador (to Italy, Costa Rica, Honduras, and Nicaragua). ${ }^{44}$ He published copiously in international law, both public and private, and founded the Instituto Hispano-Luso-Americano de Derecho Internacional. He was also member of the Inter-American Juridical Committee from July 3, 1946 to his death, on December 15, 1979. ${ }^{45}$

Of these six men, we do not know who was actually responsible for the provision on the right to science. We know that the essence of the right to science was written during the redaction of the first draft and remained largely unchanged in the final draft. We know who signed the first and second drafts. We know that Fenwick and Campos were the two members of the Committee who authored both the first and second, and that Campos was the Chairman of the Committee. However, we do not know much more than that. The hunt for the intellectual father(s) of the right to science is probably one of the most interesting puzzles for historians of international law.

We do know a little more about the documents that inspired the members of the Committee. Writing the first international declaration of human rights was a daunting intellectual and political task. Articulating key concepts and finding the best words was both a legal and a linguistic challenge, and the Committee had little in the way of wording from which to borrow. The Chapultepec Conference had given the Committee limited guidance. The only language that could remotely connect to the right to science is found in Resolution XI: "The goal of the state is the happiness of man within society. The interests of society must be harmonized with the rights of the individual. The American man does not conceive to live without justice. Nor does he conceive to live without freedom." ${ }^{46}$ Granted, the Committee did not work in a vacuum. It could draw from a rich tradition of human rights and rule of law nurtured in the West since the Enlightenment, and on specific Latin American tradition. They had at their disposal several drafts and projects on human

43 Ibid

44 Ibid.

45 Ibid.

$4^{6}$ "El fin del Estado es la felicidad del hombre dentro de la sociedad. Deben armonizarse los intereses de la sociedad con los derechos del individuo. El hombre americano no concibe vivir sin justicia. Tampoco concibe vivir sin libertad.” Declaración de México (Resolución XI) del 6 de marzo de 1945, inciso 12. 
rights that had been prepared since the 1920s by various organizations. Specifically, the Committee acknowledged having taken into consideration at least four main sources while drafting the Declaration: ${ }^{47}$

(1) The Declaration of International Rights of Men (Déclaration des droits internationaux de l'homme) of the International Law Institute (Institut de Droit International) (October 12, 1929);

(2) American Law Institute Statement of Essential Human Rights (1942-1945);

(3) Preliminary Report of the Commission to Study the Organization of Peace (1940);

(4) Declaration of Philadelphia of the International Labor Committee (1944).

Yet, none of these contained anything about a right to benefit from progress in science and technology. The ILI Declaration of International Rights of Men was a short document of only six articles, providing only for a generic duty not to discriminate and few basic freedoms, but made no mention of the right to science or "rights of science," such as freedom of speech and expression. ${ }^{4}$ The American Law Institute Statement of Essential Human Rights included the right to education (Article 11), albeit without mentioning academic freedom, and several other economic, social, and cultural rights, but made no mention of the right to science either. ${ }^{49}$ It addressed freedom of expression, opinion, and dissemination, dedicating an article each to Freedom of Opinion and to Freedom of Expression. ${ }^{\circ}$ However, these articles focused on the press and media and no mention was made to the freedom to investigate. Neither the 1944 Declaration of Philadelphia of the International Labor Committee mentioned the right to science or the rights of science. All it did was "reaffirm the fundamental principles on which the Organization is based and, in particular, that: (b) freedom of expression and of association are essential to sustained progress." ${ }^{11}$ Finally, the 1940 Preliminary Report of the Commission to Study the Organization of Peace contained a general statement on the positive and negative effects of science on international life and the need for international institutions to solve the problem. However, it did not contain a list of rights, and certainly nothing that could be borrowed by the drafters of the American Declaration. ${ }^{2}$

47 First Draft, supra note 17, pp. 18-20.

$4^{8}$ Institut de Droit International, Annuaire de l'institut de droit international, New York session, 1929, Vol. 35-II, 1929, pp. 110-138.

49 American Law Institute, Committee of Advisers on Essential Human Rights, Statement of Essential Human Rights (1945), Americans United for World Organization, New York, 1945, Art. 11.

50 Ibid., Arts. 2 and 3.

51 International Labor Committee, Declaration Concerning the Aims and Purposes of the International Labour Organisation, adopted at the 26th session of the ILO, Philadelphia, 10 May 1944, Art. I.

52 Commission to Study the Organization of Peace, "Preliminary Report, November 1940," in Commission to Study the Organization of Peace, Building Peace: Reports of the Commission to Study the Organization of Peace (1939-1972), Vol. I, Scarecrow, NY, 1973, pp. 2-3; Smith Simpson, 
Thus, it seems the members of the Committee drew mostly from their own experience and readings to draft the articles addressing the right to science and the rights of science. The question of whether and how a statement of worldwide rights and fundamental freedoms should refer to science and technology was new to global discourse. The fact that the members of the Committee were independent experts and not State representatives is noteworthy, as their personal character and idiosyncrasies probably had a heightened impact on the drafts. As we will see, the Bogotá conference adopted a final text that was considerably more succinct and more tightly worded.

As to the right to science in specific, the first draft (Anteproyecto) articulated it as follows:

Article XV: Right to Share in Benefits of Science.

Every person has the right to share in the benefits accruing from the discoveries and inventions of science, under conditions which permit a fair return to the industry and skill of those responsible for the discovery or invention.

The state has the duty to encourage the development of the arts and sciences, but it must see to it that the laws for the protection of trade-marks, patents and copyrights are not used for the establishment of monopolies which might prevent all persons from sharing in the benefits of science. It is the duty of the state to protect the citizens against the use of scientific discoveries in a manner to create fear and unrest among the people. ${ }^{53}$

The first draft set several of the key issues regarding the right to science that will determine its future shape and the discourse about it. First, it affirmed the "right to science," that is to say, the "right to share in the benefits accruing from the discoveries and inventions of science." ${ }^{54}$ However, the draft did not discuss the "rights of science" other than declaring that: "The state has the duty to encourage the development of the arts and sciences." 55 Arguably, that included the duty of the state not to arbitrarily interfere with the development of science and technology too, but it would be several years before the rights of science would be spelled out in Article 15.3 of the Covenant on Economic, Social and Cultural Rights.

The first draft also introduced the principle that there should be limits to science, and the more controversial idea that science should develop in a certain direction. The issue of whether science should have a direction and limits, still very hotly debated to this day, would have its first full discussion during the drafting of the Universal Declaration, but it surfaced here first. Actually, the draft seems to see

"The Commission to Study the Organization of Peace," American Political Science Review, Vol. 35, no. 2 (Apr. 1941), pp. 317-324, p. 321. See also James T. Shotwell, A Discussion of the Preliminary Report, Reprint of Radio Broadcast delivered November 9, 1940 over the Columbia Broadcasting System.

53 First Draft, supra note 17 , Art. XV, p. $4^{8}$.

54 Ibid., Art. XV, first paragraph.

55 Ibid., second paragraph. 
science as a threat ("It is the duty of the state to protect the citizens against the use of scientific discoveries in a manner to create fear and unrest among the people"), but this needs to be put in its historical context.

In the Commentary to the first draft, the Committee noted:

The last sentence of the article, referring to discoveries which create fear and unrest among the people, is obviously directed against the recent discovery of the means of making atomic energy available for destructive purposes. Here the protection to be given by the state to its nationals will be contingent upon the cooperation of other states in taking similar action. In the presence of this newest discovery of science it may be said that the first and foremost international right of man is now no longer the right to his own personal existence or to his own personal liberty or other associated rights, but rather his right to the existence of the civilization of which he is part and without which life would be intolerable even if he himself personally survived destruction. The "freedom from fear" which the Atlantic Charter contemplated as one of the results of the peace to be established after the war takes on a larger meaning in the light of the newly-discovered means of carrying the devastation of war to its logical extreme. ${ }^{56}$

The first draft was also the first international legal document to attempt to strike a balance between the right to benefit from science and the need to ensure those who develop science and technology have a fair return. "Every person has the right to share in the benefits accruing from the discoveries and inventions of science, under conditions which permit a fair return to the industry and skill of those responsible for the discovery or invention." 57 It was the first salvo in the long battle between the right to benefit from progress in science and technology and intellectual property rights. In the Committee's own words:

The principle upon which Article XV of the draft Declaration proceeds is that the democratic state is a cooperative commonwealth, in which the opportunities for discovery and invention are the result of many generations of progressive effort, and that each generation is the heir of the civilization which preceded it and as such is entitled to share collectively in the benefit which its men of greater genius are able to draw from the conditions placed at their disposal. At the same time the Article recognizes the necessity of rewarding the industry and skill of the discoverer or inventor and thus encouraging the patient study and research which may lead to new advances in the field of science..$^{8}$

Yet, mindful of having potentially opened a Pandora's box, the Committee hastened to add that the need to ensure a fair return to those who advance science and technology must not come at the expense of the duty to ensure all persons could share in the benefits of science. ${ }^{59}$ Again, from the Commentary:

$5^{6} \quad$ First Draft, supra note 17, pp. 48-49.

57 Ibid., Art. XV, first paragraph, p. 9.

$5^{8}$ Ibid., p. $4^{8}$.

59 Ibid., Art. XV, second paragraph, p. 9. 
Here, as in the case of the right to work, a balance must be sought between encouragement of individual initiative by the grant of patents and copyrights and the protection of the public against the abuse of the special privileges thus granted. The duty of the state to protect the individual against monopolies in the exploitation of natural resources of the state is recognized in the legislation of all American states; and it is equally the duty of the state to control the use of trade-marks and patents so as to prevent similar monopolies in the production or distribution of the articles thus protected against competition. ${ }^{60}$

As to the right to freedom of expression and opinion, a right particularly important for scientists and inventors, the Preliminary Draft contained a very long and detailed Article (III). For sake of brevity, it will not be discussed here. The text can be found in Table 2.2. All that needs to be said here is that nothing suggests that the Committee considered the right to freedom of expression and opinion to be particularly relevant for scientific inquiry and research. The Commentary of the Preliminary Draft discusses the media at length, including the press, radio, and cinema, and limits to the freedom of expression and opinion and censorship, but it does not touch upon scientists and their special needs. ${ }^{61}$

The Committee transmitted the first draft, accompanied by a "long and very carefully written report, in which the subject of the rights of man was analyzed in general, the precedents in jurisprudence and the acts of international bodies set forth, and one by one, the proposed clauses were commented upon and justified, ", ${ }^{62}$ to the States members of the Inter-American system for comment. ${ }^{63}$ Once they received the comments back, they produced the second and final draft. Article XV changed little between the first and second draft. Table 2.1 highlights the changes. They were minimal, either because it was as good as it could be or, more likely, because states preferred focusing on more crucial rights and did not attach to this one particular importance. Thus, the core of the right to science, as well as most of the freedom of information and opinion, was set by December 1945 .

It is remarkable that the first draft gave the right to science its own dignity, separate and distinct from the "right to culture," and that this survived to the second draft. However, at the same time, the Inter-American Juridical Committee nodded towards the subsequent, momentous development, when they stated that: "The state has the duty to encourage the development of the arts and sciences." ${ }^{64}$

64 First Draft, supra note 17, Art. XV, second paragraph. 
TABLE 2.1 Comparison of the provisions on the right to science in the drafts of the Inter-American Juridical Committee and the final text of the American Declaration (differences between previous and subsequent versions are in italics)

\begin{tabular}{|c|c|c|}
\hline $\begin{array}{l}\text { Preliminary Draft by the } \\
\text { Inter-American Juridical } \\
\text { Committee ( } 31 \text { Dec. 1945) }\end{array}$ & $\begin{array}{l}\text { Final Draft by the Inter- } \\
\text { American Juridical } \\
\text { Committee ( } 8 \text { Dec. 1947) }\end{array}$ & $\begin{array}{l}\text { American Declaration of the } \\
\text { Rights and Duties of Men } \\
\text { (30 April 1948) }\end{array}$ \\
\hline $\begin{array}{l}\text { Article XV: Right to Share in } \\
\text { Benefits of Science. } \\
\text { Every person has the right to } \\
\text { share in the benefits } \\
\text { accruing from the discov- } \\
\text { eries and inventions of sci- } \\
\text { ence, under conditions } \\
\text { which permit a fair return } \\
\text { to the industry and skill of } \\
\text { those responsible for the } \\
\text { discovery or invention. } \\
\text { The state has the duty to } \\
\text { encourage the development } \\
\text { of the arts and sciences, but } \\
\text { it must see to it that the laws } \\
\text { for the protection of trade- } \\
\text { marks, patents and copy- } \\
\text { rights are not used for the } \\
\text { establishment of monop- } \\
\text { olies which might prevent all } \\
\text { persons from sharing in the } \\
\text { benefits of science. It is the } \\
\text { duty of the state to protect } \\
\text { the citizens against the use } \\
\text { of scientific discoveries in } \\
\text { a manner to create fear and } \\
\text { unrest among the people. }\end{array}$ & $\begin{array}{l}\text { Article XV: Right to Share in } \\
\text { Benefits of Science. } \\
\text { Every person has the right to } \\
\text { share in the benefits } \\
\text { accruing from the discov- } \\
\text { eries and inventions of sci- } \\
\text { ence, under conditions } \\
\text { which permit a fair return } \\
\text { to the industry and skill of } \\
\text { those responsible for the } \\
\text { discovery or invention. } \\
\text { The state has the duty to } \\
\text { encourage the develop- } \\
\text { ment of the arts and sci- } \\
\text { ences, but it must see to it } \\
\text { that the laws for the pro- } \\
\text { tection of literary and artis- } \\
\text { tic copyrights, patents, and } \\
\text { industrial and commercial } \\
\text { trademarks are not used for } \\
\text { the establishment of mon- } \\
\text { opolies. It is the duty of the } \\
\text { state to protect the citizens } \\
\text { against the use of scientific } \\
\text { discoveries in a manner to } \\
\text { create fear and unrest. }\end{array}$ & $\begin{array}{l}\text { Article XIII: Right to the } \\
\text { Benefits of Culture. } \\
\text { Every person has the right to } \\
\text { take part in the cultural life } \\
\text { of the community, to enjoy } \\
\text { the arts, and to participate } \\
\text { in the benefits that result } \\
\text { from intellectual progress, } \\
\text { especially scientific } \\
\text { discoveries. } \\
\text { He likewise has the right to the } \\
\text { protection of his moral and } \\
\text { material interests as regards } \\
\text { his inventions or any liter- } \\
\text { ary, scientific or artistic } \\
\text { works of which he is the } \\
\text { author. }\end{array}$ \\
\hline
\end{tabular}

\subsubsection{The Ninth Conference of American States (Bogotá, Colombia, Spring 1948)}

The second draft of the Inter-American Juridical Committee was considered at the next conference of the American States, the ninth. Twenty-one states, all the American Republics, as they were called, participated. ${ }^{65}$ Most were represented at

65 Honduras, Guatemala, Chile, Uruguay, Cuba, USA, Dominican Republic, Bolivia, Peru, Nicaragua, Mexico, Panama, El Salvador, Paraguay, Costa Rica, Ecuador, Brazil, Haiti, Venezuela, Argentina, and Colombia. Canada did not participate, nor any of the European territories and colonies in the Caribbean. 
TABLE 2.2 Comparison of the provisions on the Freedom of Investigation, Opinion, Expression and Dissemination in the drafts of the Inter-American Juridical Committee and the final text of the American Declaration

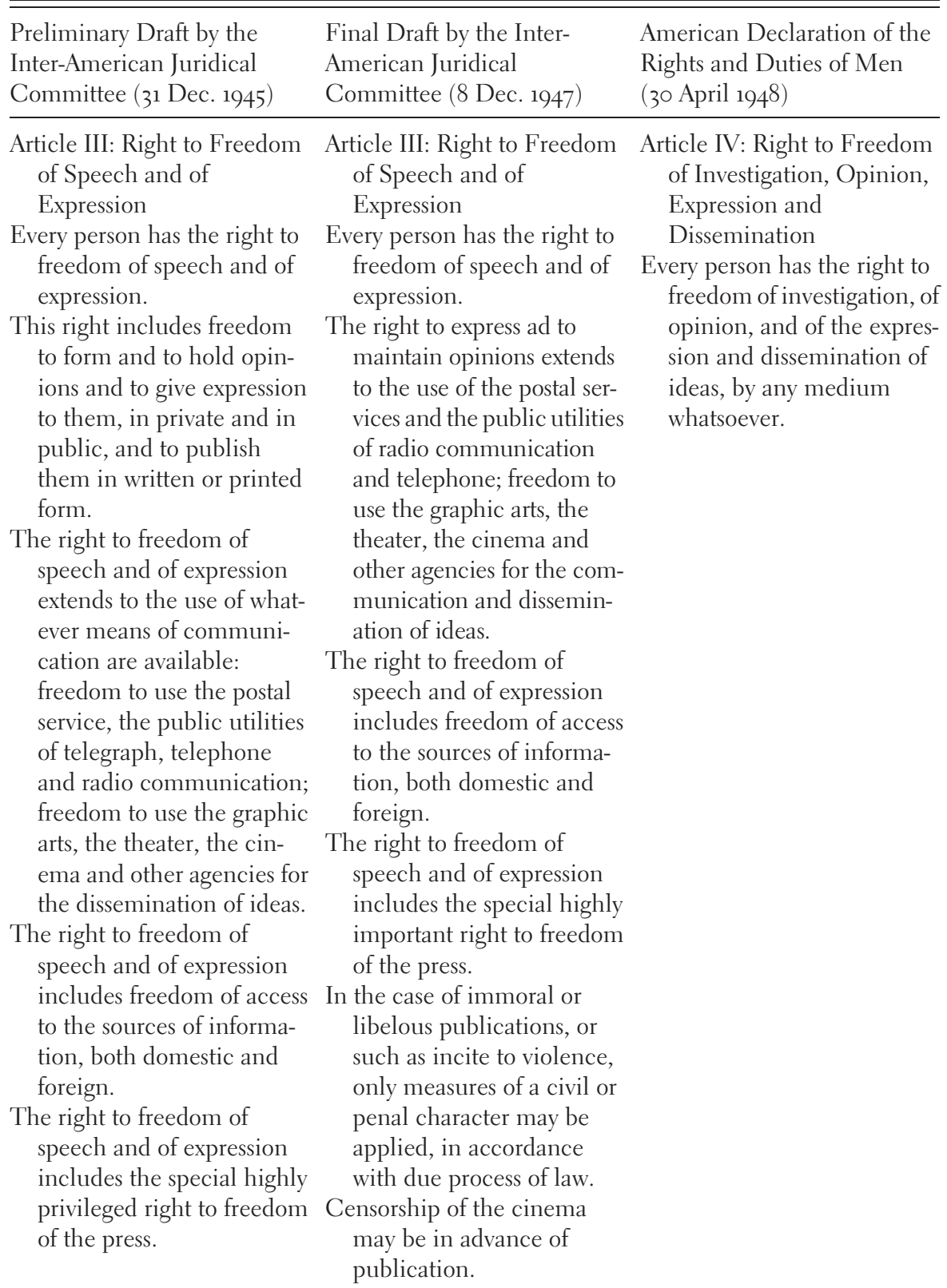


TABLE 2.2 (continued)

\begin{tabular}{lll}
\hline \hline $\begin{array}{l}\text { Preliminary Draft by the } \\
\text { Inter-American Juridical }\end{array}$ & $\begin{array}{l}\text { Final Draft by the Inter- } \\
\text { American Juridical }\end{array}$ & $\begin{array}{l}\text { American Declaration of the } \\
\text { Rights and Duties of Men } \\
\text { Committee (31 Dec. 1945) }\end{array}$ \\
$\begin{array}{l}\text { Committee (8 Dec. 1947) } \\
\text { (30 April 1948) }\end{array}$
\end{tabular}

The only limitations which the state may impose upon this freedom are those prescribed by general laws looking to the protection of the public peace against slanderous or libellous defamation of others, and against indecent language or publications, and language or publications directly provocative of violence among the people.

Censorship of the press is prohibited, whether by direct or indirect means, and all limitations imposed in the interest of public order shall only be applied subsequently to the publication of the material alleged to be of the offensive character described in the law.

Censorship of the cinema may be in advance of publication, taking into account the particular form of publication and the necessity of protecting the public against matters offensive to accepted standards of conduct. The state may not retain a monopoly of radio broadcasting so as to deny to the individual the opportunity for the free expression of opinion through that instrumentality of communication. 
a high level. Eleven delegations were headed by their Minister of Foreign Affairs or the equivalent. ${ }^{66}$ The task of the drafting the declaration was entrusted to the VI Committee (Juridical-Political Issues), and from it to a working group (SubCommittee A) consisting of representatives of Argentina, Bolivia, Brazil, Colombia, Cuba, Mexico, Peru, the U.S., Uruguay, and Venezuela. ${ }^{67}$ The working group met first on April 17, 1948. It started from the "fairly acceptable draft" produced by the Inter-American Juridical Committee, but produced a new text, quite different from the one prepared by the Committee, taking into account the amendments and proposals presented by numerous delegations, and discussions had within the working group. ${ }^{69}$ Besides the draft of the Inter-American Juridical Committee (the Final Draft), and the amendments and proposals presented by numerous delegations, the working group considered also the draft of the Universal Declaration of Human Rights circulated at the Human Rights Commission's second session, in December 1947. ${ }^{70}$ The text hammered out by the working group then went back to the VI Committee, where it was approved. ${ }^{71}$ It is said that the discussions on social, economic, and cultural rights, including the right to science, were particularly intense..$^{72}$ Finally, on May 2, 1948, the Plenary unanimously approved the text sent by the VI Committee without discussion and as a nonbinding resolution of the Conference.

The U.S. delegation participated at all stages of the drafting of the Declaration (Working Group, VI Committee and Plenary). It obtained a modification of the article on the right to health, to ensure it would not contain any preference between public and private control of health and sanitation facilities, and it

66 The United States was represented by the U.S. Secretary of State, George C. Marshall, who was present for most of the conference and left only on April 24, when all key decisions had been taken. Ninth International Conference, supra note 11, p. 4.

${ }_{7}$ Report of the Working Group on Human Rights: Report of the Rapporteur of the Working Group on Human Rights, Ninth International Conference (Bogotá, 1948), in Buergenthal and Norris, supra note 18, Part I, Chapter IV, p. 15 (Section D.1.1) [hereinafter Report of the Working Group on Human Rights]. Uruguay ended up not sending a representative to sit in the working group because they had not enough diplomats to attend all meetings. Ibid., p. 16 (Section D.1.3). These are the representatives who sat in the working group: Luis Fernan Cisneros (Peru) and Guy Pérez Cisneros (Cuba), respectively as President and Rapporteur. Gerardo Melguizo served the Group as Secretary. Then, Enrique V. Coreminas (Argentina); Alberto Salinas López (Bolivia), Camillo de Oliveira (Brazil), Luis López de Mesa (Colombia), Edward A. Jamison (United States), German Fernandez del Castillo (Mexico) and Melchor Monteverde (Venezuela), as members. Ibid., pp. 15-16 (Section D.1.3).

68 "Memorandum by the Secretary of State to Diplomatic Representatives in the American Republic, Washington, March 9, 1948," in Foreign Relations of the United States, 1948, The Western Hemisphere, Volume IX.

69 The text of all amendments and proposals presented at the Ninth Conference (CB 101, 112, 125, 139, $163,194,328,337,400,401$ and 420 ) can be found in IX Conferencia, supra note 18, pp. $440 \mathrm{ff}$.

70 UN Economic and Social Council, E/600, 17 December 1947, Annex A, Part I; Report of the Working Group on Human Rights, supra note 67, p. 15 (Section D.1.3).

${ }^{71}$ The text and the report of the Rapporteur are included in IX Conferencia, supra note 18, pp. 494-504, 510.

72 Report of the Working Group on Human Rights, supra note 67, Chapter IV, p. 22. 
successfully opposed a proposal for including a statement on the right of resistance to oppression. ${ }^{73}$ However, it unsuccessfully opposed the inclusion of a statement on the right to protection of authors and inventors in the article on the "right to culture." 74 The U.S. representative (Jack B. Tate) argued that it was not an essential human right. ${ }^{75}$ However, strongly supported by Cuba, the article was left unchanged..$^{76}$

In the end, the Conference produced a "lengthy document whose principal defect is considerable verbiage," as the U.S. Ambassador to Colombia sneeringly noted. ${ }^{77}$ It consists of a preamble and two chapters. The preamble sets forth general principles, chapter one contains rights (both civil and political and, crucially, economic, social, and cultural rights) and chapter two contains duties. To limit our discussion only to the provisions regarding the right to science, these are the relevant provisions in the final text of the American Declaration on the Rights and Duties of Man:

WHEREAS: The American peoples have acknowledged the dignity of the individual, and their national constitutions recognize that juridical and political institutions, which regulate life in human society, have as their principal aim the protection of the essential rights of man and the creation of circumstances that will permit him to achieve spiritual and material progress and attain happiness;

Preamble: ... Since culture is the highest social and historical expression of that spiritual development, it is the duty of man to preserve, practice and foster culture by every means within his power; And, since moral conduct constitutes the noblest flowering of culture, it is the duty of every man always to hold it in high respect. ...

Right to freedom of investigation, opinion, expression and dissemination.

Article IV. Every person has the right to freedom of investigation, of opinion, and of the expression and dissemination of ideas, by any medium whatsoever.

‥

Right to the benefits of culture.

Article XIII. Every person has the right to take part in the cultural life of the community, to enjoy the arts, and to participate in the benefits that result from intellectual progress, especially scientific discoveries.

73 Ninth International Conference, supra note 11, p. 81.

74 U.S. Department of State, Office of the Historian, "The Ambassador in Colombia (Beaulac) to the Secretary of State, 25 April 1948," in Foreign Relations of the United States, 1948, The Western Hemisphere, Volume IX [hereafter Beaulac 25 April]; IX Conferencia, supra note 18, p. 582.

75 Beaulac 25 April, supra note 74; Ninth International Conference, supra note 11, p. 81; IX Conferencia, supra note 18 , p. 582 .

$7^{6}$ Beaulac 25 April, supra note 74; IX Conferencia, supra note 18, p. 582.

77 "The Ambassador in Colombia (Beaulac) to the Secretary of State, 26 April 1948," in Foreign Relations of the United States, 1948, The Western Hemisphere, Volume IX. 
He likewise has the right to the protection of his moral and material interests as regards his inventions or any literary, scientific or artistic works of which he is the author. $^{78}$

Tables 2.1 and 2.2 compare the final text of the American Declaration with the drafts produced by the Inter-American Committee. The resulting Article XIII, on the right to science, and Article IV, on freedom of investigation, of opinion, and of the expression and dissemination of ideas, are considerably terser than the corresponding articles in the drafts of the Inter-American Commission of Jurists. That should be no surprise since the text adopted in Bogotá was the result of a diplomatic effort rather than an intellectual project, as the drafts of the Inter-American Commission of Jurists had been.

The differences between the draft declaration and the final one are many and significant. In the Inter-American Commission's drafts, Article XV was entitled "Right to Share in Benefits of Science." In the final text adopted in Bogotá, the right to science ends up in Article XIII, entitled "Right to the Benefits of Culture." Thus, the right to science became part of the broader right to "take part in the cultural life of the community, to enjoy the arts, and to participate in the benefits that result from intellectual progress." ${ }^{79}$ It was a significant demotion of the right to science, which from then on would be lumped together with other cultural phenomena, like figurative arts, literature, sport, or cuisine. Article XIII treats science almost as an afterthought ("especially scientific discoveries"). ${ }^{8 \circ}$ On the other hand, Article III of the Inter-American Commission's drafts, entitled "Right to Freedom of Speech and of Expression," was retitled to "Right to Freedom of Investigation, Opinion, Expression and Dissemination” (Article IV). The particular addition of the "freedom of investigation" is notable as it opened the door for the extension of the freedom of expression to scientists, qua scientist and not as mere citizens.

Second, the "right to share in the benefits accruing from the discoveries and inventions of science" of the drafts, became the "right to ... participate in the benefits that result from intellectual progress, especially scientific discoveries" of the American Declaration. The Universal Declaration reverted to the language of the drafts, speaking of "right to . . share in scientific advancement and its benefits." 8 1 The distinction is crucial. The travaux préparatoires of the Universal Declaration show a debate took place on whether the right should be understood as being only about enjoying passively the benefits or is also about taking part in the scientific enterprise in a broader sense. ${ }^{82}$ As Mikel Mancisidor has remarked, the word "share" in the phrase "the right to share in scientific advancement and its benefits" indicates

$7^{8}$ American Declaration, supra note 1, preamble, Arts. IV and XIII.

79 Ibid., Art. XIII, first paragraph.

so Ibid.

81 Universal Declaration, supra note 2, Art. 27.1.

82 Morsink, supra note 5, pp. 217-222. 
an idea of action or agency. ${ }^{83}$ According to him, the Draft and the Universal Declaration, but not the American Declaration, advocate "a view of 'participation' which includes science popularization, participation in scientific creation and in scientific policy, citizen science, gender equality, the freedoms of those doing science and some other aspects which are in addition to the right to "benefit from scientific applications." " ${ }_{4}$

As the drafts, the Declaration recognized the need to ensure fair return to those who advance science, but it did it in more succinct and subtly different terms: "[Every person] has the right to the protection of his moral and material interests as regards his inventions or any literary, scientific or artistic works of which he is the author." Compare this with lengthy provision in the first:

Every person has the right to share in the benefits accruing from the discoveries and inventions of science, under conditions which permit a fair return to the industry and skill of those responsible for the discovery or invention. The state has the duty to encourage the development of the arts and sciences, but it must see to it that the laws for the protection of trade-marks, patents and copy-rights are not used for the establishment of monopolies which might prevent all persons from sharing in the benefits of science. ${ }^{85}$

Note that the American Declaration does not speak of "fair return" but rather of "protection of moral and material interests."

As has been said, this particular aspect of the right to science was one of the few, if not the only, to be discussed in Bogotá. The U.S. delegation strongly opposed the inclusion of a right to "protection of moral and material interests" on the ground that it not consider it an essential human right, but lost to the Latin American bloc. Considering the contemporary debates between the Global North and the Global South, where the former advocates for strong intellectual property rights, while the latter argues that intellectual property protection robs them of the right to benefit from scientific progress, the debate in Bogotá over the inclusion of a right to "protection of moral and material interests" is surprising. What pushed Latin American countries to insist on the need to protect them?

According to Lea Shaver,

[t] he enduring controversy over the protection element reflects an underlying international disagreement about the underpinnings of copyright law. Within the common law tradition, the exclusive rights of authors to control publication of their works are considered solely in economic and utilitarian terms as providing incentives for creativity. Within the civil law tradition, the natural law concept of droit d'auteur recognizes additional, inalienable rights of authors grounded in the ethical

83 Mikel Mancisidor, "Is there Such a Thing as A Human Right to Science in International Law?," ESIL Reflections, Vol. 4, No. 1, April 2015, p. 2.

84 Ibid.

85 First Draft, supra note 17, Article XV. 
conception of the creative product as an extension of the creator's personality. From the civil law perspective, then, authors' rights were grounded in the same basis as other human rights and should sensibly be included in the Declaration. From the common law perspective, a moral rights provision risked introducing a complex area of disagreement that more appropriately belonged to the realm of economic and trade law. 86

The debate continued in the context of the drafting of the Universal Declaration, as well as in that of the Covenant on Economic, Social and Political Rights. The United Kingdom, a country of the common law tradition, joined the argument on the side of the United States, while France, from the civil law tradition, sided with the Latin American states, sharing their view of the issue. Nevertheless, "protection of moral and material interests" remained a feature of the right to science and the rights of science in all subsequent articulations of the rights. That is because of the numeric superiority of civil law countries over common law countries, and because the USA, UK, and other developed countries eventually adopted strong intellectual property and copyrights protection in the 1980s.

Finally, although the Latin American bloc was successful in ensuring the final text of the American Declaration contained the duty to protect "moral and material interests" of scientists, inventors and authors, lamentably the duty of states to ensure that "laws for the protection of trade-marks, patents and copy-rights are not used for the establishment of monopolies which might prevent all persons from sharing in the benefits of science" was lost, never to resurface again. One can only wonder how, had that wording of the Draft made it to the American and the Universal Declarations, international and national intellectual protection regimes might have developed.

The "duty of the state to protect the citizens against the use of scientific discoveries in a manner to create fear and unrest among the people" was lost, too, but it came back again during the drafting of the Universal Declaration in the form of a lively debate between the East and the West on the purpose and limits of science.

\subsection{THE AFTERMATH OF THE AMERICAN DECLARATION}

The wording of the right to science proposed by the Inter-American Committee was fundamentally changed by the American States' meeting in Bogotá, to the point of being almost unrecognizable. However, the wording proposed by the Committee came back into play during the drafting the Universal Declaration. John Humphrey, the Director of the United Nations Division of Human Rights, who prepared the first draft of the Universal Declaration, relied on the drafts prepared by the Committee. Chile suggested relying on the Committee's drafts, too. However, in the end, the Third Committee of the General Assembly opted to essentially copy and paste 
Article XIII of the American Declaration into Article 27 of the Universal Declaration.

Although the current standard wording of the right to science departs from the one chosen by the members of the Inter-American Committee, there is no doubt that the right to science came to be first in Rio de Janeiro, on December 31, 1945. There is no sign of it before then and it went a long way after then. Since Rio is famous for its extravagant celebrations of New Year's Eve, one can imagine the four members of the Committee to be in a rush to adopt the Preliminary Draft of a Declaration on the Rights and Duties of Men, with the new right to science in it, before joining the festivities. One might wonder whether they suspected how far the idea would have gone. 